\title{
Public quality - for whom and how? Integrating public core values with quality management
}

Mattias Elg, Elin Wihlborg and Mattias Örnerheim

\section{Linköping University Post Print}

\section{Tweet}

N.B.: When citing this work, cite the original article.

This is an electronic version of an article published in:

Mattias Elg, Elin Wihlborg and Mattias Örnerheim, Public quality - for whom and how? Integrating public core values with quality management, 2015, Total quality management and business excellence (Online).

Total quality management and business excellence (Online) is available online at informaworldTM:

http://dx.doi.org/10.1080/14783363.2015.1087841

Copyright: Taylor \&amp; Francis

http://www.tandf.co.uk/journals/default.asp

Postprint available at: Linköping University Electronic Press

http://urn.kb.se/resolve?urn=urn:nbn:se:liu:diva-128224 


\section{Public quality - for whom and how? Integrating public core values with quality management}

\section{Mattias Elg, Elin Wihlborg \& Mattias Örnerheim}

To cite this article: Mattias Elg, Elin Wihlborg \& Mattias Örnerheim (2015): Public quality for whom and how? Integrating public core values with quality management, Total Quality Management \& Business Excellence, DOI: 10.1080/14783363.2015.1087841

To link to this article: http://dx.doi.org/10.1080/14783363.2015.1087841

Published online: 28 Sep 2015.

Submit your article to this journal $\sqsubset$

山 Article views: 67

Q View related articles $\square$

View Crossmark data ¿ 


\title{
Public quality - for whom and how? Integrating public core values with quality management
}

\author{
Mattias Elg*, Elin Wihlborg and Mattias Örnerheim \\ Department of Management and Engineering, Linköping University, SE-581 83 Linköping, \\ Sweden
}

\begin{abstract}
Quality management (QM) plays an important role in public organisations' efforts to create better access to, and effectiveness of, specific services. When transferring QM models from market-based firms to public services provided by public organisations, several basic contrasts and even contradictions must be addressed. Core values of the public sector differ from those of the private sector, but what are the consequences of this distinction? In this article we discuss the importance of four central arguments on public services: rights and access have to be considered; equality is an important facet of public services; coerciveness is a unique feature of public services; and legitimacy can be improved by high-quality services. These arguments have not been discussed explicitly in the context of QM. Adding these central aspects of public services to the QM field could generate more sustainable ways for developing quality and QM in public services in particular and the public sector in general.
\end{abstract}

Keywords: public sector; customer; citizen; quality management

\section{Introduction}

One of contemporary society's most important concerns is the development and provision of high-quality public services. Citizens expect to have access to, and take part in, various public services from the cradle to the grave. Our common interests put high demands on the systems that are supposed to deliver these services. The complex interplay of actors and goals in the public sector provides a challenge for all involved.

Ideas from quality management (QM) play an important role in the public sector's striving to create better access to, and effectiveness of, specific services. Various actors in the public system work to improve the quality of public services. The application of QM programmes in public sector takes on many different forms. This includes, for example, policy development initiatives (Bejerot \& Hasselbladh, 2013), performance measurement frameworks (Elg, Palmberg Broryd, \& Kollberg, 2013; Pollitt, 2013), ISO 9000 (Moreland \& Clark, 1998), EFQM models (Wiśniewska \& Szczepańska, 2014), and quality improvement programmes (Berwick, 1989; Elg, Stenberg, Kammerlind, Tullberg, \& Olsson, 2011). The focus on QM in public services is also evidenced by various forms of evaluations (Vedung, 2008) and audit (Pollitt \& Bouckaert, 1999; Power, 1999). Thus, rather than a well-defined concept, quality may be seen as a more general umbrella term for improving public sector performance (McAdam, Reid, \& Saulters, 2002).

Stringham $(2004$, p. 203) sees a potential if QM is managed as a '... comprehensive, unified quality program that integrates a sophisticated strategic planning process'. Such an approach integrates policy goals and QM, which Nielsen (2013) identifies as a key for successful QM in public services. When QM is used in public service management, specific contextual

${ }^{*}$ Corresponding author. Email: mattias.elg@liu.se 
and organisational characteristics must be considered based on the core values of the public in public services (Bouckaert \& Peters, 2002; Pollitt, 2012; Walker \& Boyne, 2009).

The core values of public services are expressed through rules based on legal certainty, publicity, and political participation, all of which are far from what a private profitmaximising organisation has to deal with when meeting the demands of customers (Christensen \& Lægreid, 2001; Hood, 1991; Pollitt \& Bouckaert, 1999). In relation to private companies, the individual is a customer; in relation to public services, the individual can have several different roles, for example, student, patient, client, or taxpayer. These roles are interconnected with the duties, rights, and expectations related to citizenship. The roles also imply involvement of the individual. The student studies, the patient rehabilitates, the client in social services fulfils duties to get benefits, and the taxpayer pays his or her taxes and make these and other services available. The production of public services is therefore not one-sided and delivered to the individual, but they are formed in partnership that extends the meanings and potential of QM. Thus there is a need to elaborate on, and clarify, the conceptualisation of public services in order to develop the practice of QM in public services.

When transferring QM models from market-based firms to public services provided by public organisations, several basic contrasts and contradictions must be addressed. Core values of the public sector differ from those of the private sector, but researchers and practitioners in the QM field largely lack the tools to understand and deal with the potential differences. This article aims to discuss contrasts and contradictions for QM in public services by elaborating on the role of customers, which differs between public and private services, and its implication on the quality of public services. The article therefore argues that there is a need to extend, adjust and adapt the conceptualisation of quality and QM when it concerns public services. Our concept of framing around the customer is motivated by the basic idea that quality is all about 'meeting or even exceeding the needs and expectations of the customer'. Based on an elaboration of the public/private distinction (on a structural level) and its implication for users (the actor level) as beneficiaries of unique services - that is, as 'customers' or citizens - we present and discuss four key arguments with consequences for QM:

- Rights and access have to be considered;

- Equality is an important facet of public services;

- Coerciveness is a unique feature of public services; and

- Legitimacy can be improved by high-quality services.

These four arguments are central to the theories and models on public services (Pollitt, 2012; Pollitt \& Bouckaert, 1999), but have not explicitly been discussed in the context of QM.

This article proceeds as follows. First, we make a brief note on methodological considerations. Second, we present a general framing of the core characteristics of the public sector from a structure-actor perspective, with a focus on public services. Then, the main part of the article is organised around the four arguments. Finally, we will open up a more general discussion on the implications of QM in public services.

\section{A brief note on methods for conceptualisations}

This article proceeds from a conceptual approach, but it builds on and addresses also practical challenges and problems regarding QM in public services. The general arguments 
presented here aim to contribute to the theoretical grounding of QM analyses of public services by integrating and elaborating on key issues in public administration, and in particular political science. The meaning of QM will be addressed on a general level, and key issues and challenges will be identified and discussed.

Our conceptualisation in this article takes an inter-disciplinary approach that focuses on and integrates core characteristics of public administration, and in particular political aspects of values and norms of the public, into the QM field. The conceptualisation builds on the deconstruction of meanings and interpretations beyond the empirical setting in both fields of research. Since QM models aim to improve production processes, they are grounded in ontology that differs from policy-based public management models that draw from the political values and norms which frame public services. Thus, this conceptualisation aims for 'inter-ontology crossovers', where theories and concepts interplay without necessarily synthesising between ontological imperatives (Geels, 2010). The ambition, therefore, is neither to fully combine, nor to merge, the perspectives, but rather to build and launch a more informed and valid conceptualisation of QM in public service. The present research is based in the Swedish context of a mature Scandinavian welfare state (Esping-Andersen, 1990; Morel, Palier, \& Palme, 2012). The outcome of this conceptualisation could still suggest improvements to the means by which public services are designed and measured in wider contexts.

\section{It is all about the customer - defining quality}

One of the more influential and commonly used definitions of quality is to meet, or even exceed, the needs and expectations of the customer. Under this definition, quality is determined by the customer. It does not matter if members of an organisation believe that their products (goods or services) are superior if the customer does not come to the same conclusion. Assuming that the customer is the ultimate evaluator of quality, an organisation must establish and improve the processes that deliver value to the customer through standardisation of work procedures, cross-functional teamwork, reduction of waste, continuous improvements, and fact-based decision-making (Deming, 1993; Schroeder, Linderman, \& Zhang, 2005; Sousa \& Voss, 2002).

A general theme in the quality discourse is that any organisation that aims to work with quality must define the customer. Without a clear picture of where to direct efforts, including design, production, marketing, and sales, a provider will not be successful (Dean \& Bowen, 1994). Narrowly defined, the customer is someone who is the recipient of products (goods or services). The customer may be the final consumer of the product, or function as an intermediary and hold, modify, or develop the product for someone else. In a broader sense, the customer is anyone who benefits from the products being offered. However, the customer does not need to be the recipient, but an individual, a group, or a part of society that perceives value in the product being offered. This broader meaning allows for a wider interpretation of the customer concept, which becomes key in relation to public services, where 'customer' stands for a more complex role.

\section{The customer of public services}

In order to survive, private organisations must provide value for their customers. According to QM theory, this idea also holds for public services, but we will show how it stretches the limits of the customer concept. Three examples illustrate this: 
- Improving the quality of public elderly care. A model developed by the Swedish National Board of Health and Welfare addresses the need to provide individualised care for elderly people, as opposed to relying on pre-existing, standardised methods.

- Improving care for people struggling with substance abuse and addiction. These coercive, public services have focused on a number of areas that are clearly influenced by ideas from QM, including access to care, teamwork, client and patient process, investigation and documentation, follow-up, safety, and management and control.

- Organising work for building-permit applicants according to different customer segments. For instance, applications can be differentiated as simple or complex, and processed accordingly. Complex applications may take longer and require more skilled personnel, while simple applications can be made with speed and accuracy.

In these examples, public services address specific beneficiaries (the elderly, the substance abuser, and the building-permit applicant). These services might seem to have customers. However, there are constraints as to what the beneficiaries can ask for, and because they are not directly paying for the services received there are no openings to pay more for better services (which would, in fact, constitute a bribe). The qualities experienced by the beneficiary might even be experienced as constraints to personal expectations (such as the rejection of a building-permit application). In this context, QM must be arranged differently, but how? To answer that question we must clarify some basic differences between public and private services.

\section{Distinctions between public and private services}

The three examples above suggest that quality is about putting the beneficiary in focus by organising work more effectively. When the beneficiary is seen as a customer, we may continue to understand these examples in the same way as we approach the subject from a market-based perspective. However, the context of the public sector provides several important restrictions and limitations.

These differences appear on both structural and actor levels (Table 1). In practice, the arrangements of service provision are often a mix of private and public arrangements. There might be a public food control on a fully market-based chain of food provision. However, if we discuss the ideal models of private and public services, we can identify some key characteristics on the structural and actor levels.

The ideal structure is a market with free entry and exit, and access for actors, and the price becomes the carrier of information. While stable (policy-based) institutional arrangements can lay a ground for an efficient market (e.g. North, 1990), the outcomes most often are formed on markets without policy interventions. The actors have their own resources to demand services on the market.

Table 1. The context for conceptualising differences between public and private services in this article.

\begin{tabular}{lll}
\hline & \multicolumn{1}{c}{ Private services } & \multicolumn{1}{c}{ Public services } \\
\hline $\begin{array}{l}\text { Structure } \\
\text { level } \\
\text { Actor level }\end{array}$ & $\begin{array}{c}\text { Market-based (free entry } \\
\text { and exit) } \\
\text { Customers }\end{array}$ & $\begin{array}{c}\text { Policy-based public arrangements (access to services } \\
\text { based on legislation) } \\
\text { Citizen beneficiary }\end{array}$ \\
\hline
\end{tabular}


However, public services are not so simply provided. They are organised in line with political decisions (made on any level of government - national, regional, or local - or in complex interplay among them) and supplied to target groups. Thus, not just anyone can demand all public services; the distribution of services does not follow the customer's willingness to pay, but rather their needs and rights. In most states, the structures of public services are based on public arrangements, from quasi-markets to fully regulated and authoritarian arrangements of services, such as courts and the police.

The interests and values of the public (the citizens) are formed through the political system, and expressed in political decisions as legislation regulating what public organisations should do, and how they should do it. This means, for instance, that one does not have automatic access to public elderly care; it has to be means-tested, and is provided when one fulfils the criteria and when resources are available (such as placement within the service level to which one is assigned). Providers of public welfare services must relate to many more actors and stakeholders than the people who receive value at the agency's end. Instead, welfare service providers need to balance many more interests, providing services in line with legislation and professional competence and practice, with a focus on the enduser of the service (Pollitt, 2013). For instance, it is not possible for a substance abuser to exit compulsory care when a formal political decision has been made in line with the legislation in use in that state. Such legislation can give the police rights to put a substance abuser in custody, or for social workers to place him or her in a care facility. These are public services that the user may not appreciate, but the benefits of the services are, in most states, deemed best for the 'customer' and in line with the values of the general public. No one, or at least few, would ask for such a service on the market, but as a public service it seems to satisfy the needs not just of the user, but of the society as a whole.

Public services are also an outcome of political processes, and thus differ among political systems. The extension of public services in different states varies in relation to norms, values, traditions, and structures (cf. Esping-Andersen, 1990; Pollitt \& Bouckaert, 1999; Walby, 2009). In international comparisons, high-quality government has shown to lead to greater trust, both towards the government and in society. High-quality government processes and reliable and impartial public services promote lower levels of corruption, higher willingness to pay taxes, and higher voter turnout and rule obedience (cf. Rothstein, 2011). Therefore, the quality of public services is not only in the interest of the individual user of the services; it also has a crucial impact on the governmental structure and society in general.

\section{The arguments - QM for public services}

Based on the general discussion on the differences between public and private services, we will now discuss the four key arguments addressed in the introduction. We will show how the uniqueness of public services has specific implications for QM in terms of rights and access, coerciveness, equality, and legitimacy.

\section{The first argument - Access to and distribution of public services}

The first consideration is how services can be and are accessed. Private services provided on the market are open to those who are willing to pay for them, and private service providers often respond quickly to changes in customer demands and preferences. However, citizens have the right to access public services. In the examples above, the elderly person had to apply for services in everyday life, the drug addict was forced to follow the care 
prescribed, and the person applying for a building permit had to fulfil the requirements of building legislation and urban planning. All these constraints are formed through legislation, and as a result of policy processes.

Access to public services is, consequently, subject to various constraints, as shown in Table 2. Actors using public services, having an interest in the quality of the service, can be viewed either as individual beneficiaries or as part of the general public. Examples of services targeting a single beneficiary include healthcare, passport provision, and public transportation. Examples of services targeting broader groups of citizens include public parks, law enforcement, and fire brigades.

Access to public services is not always open. There may be constraints in the form of means-testing or other regulations that make it more difficult for citizens to access public services. Another limit to access is waiting time, for instance, Scandinavian welfare states face excessively long waits for healthcare. There are also some public services without exit opportunities (further discussed in argument three below), including coercive services such as school.

Another important distinction between public and private services arises when the customer/beneficiary is dissatisfied with the quality of the delivered service. In dealing with private organisations, one may either use exit or raise their voice as a customer. This opportunity is often limited in public services because one's opportunities to exit or raise their voice are constrained by legislation. Exit is for some services only possible by emigration.

There is an obvious need for more flexible and diverse QM approaches for public services that take into account the complex arrangements of rights and access. In addition, public services must apply a broader grasp of the general public (as their opinions are expressed through policy-making) beyond the single user or beneficiary, in the interest of equality.

\section{The second argument - Public services must be equal}

Modern Western welfare states are grounded in, and motivated by, arguments of equality (cf. Esping-Andersen, 1990; Morel et al., 2012). Thus, equality is key to the design and arrangement of public services. Impartial treatment of citizens is an indication of the quality of government, and a foundation of Western welfare states (Agnafors, 2013; Rothstein \& Teorell, 2008). The equal distribution of resources, as public services, is also seen as a key to citizens' willingness to contribute to a system of publicly funded services (Rothstein \& Uslaner, 2005).

Table 2. The differences in access to and distribution of services in private and public service settings.

\begin{tabular}{llll}
\hline & \multicolumn{1}{c}{ Private services } & Public services & \\
\hline $\begin{array}{c}\text { Access to } \\
\text { services }\end{array}$ & Open on the market & Open to all & $\begin{array}{c}\text {. f for a single beneficiary } \\
\text { If the beneficiary meets the } \\
\text { requirements of the } \\
\text { legislation }\end{array}$ \\
$\begin{array}{c}\text { Distribution of } \\
\text { services }\end{array}$ & $\begin{array}{c}\text { Customers' willingness to } \\
\text { pay; market adjusts to } \\
\text { customer demands and } \\
\text { preferences }\end{array}$ & $\begin{array}{c}\text { In line with entry } \\
\text { restrictions as } \\
\text { formulated in } \\
\text { legislation }\end{array}$ & $\begin{array}{c}\text { Means-tested imperative } \\
\text { arrangements, such as } \\
\text { compulsory school } \\
\text { attendance }\end{array}$ \\
\hline
\end{tabular}


Table 3. Equality in public services regarding access and funding.

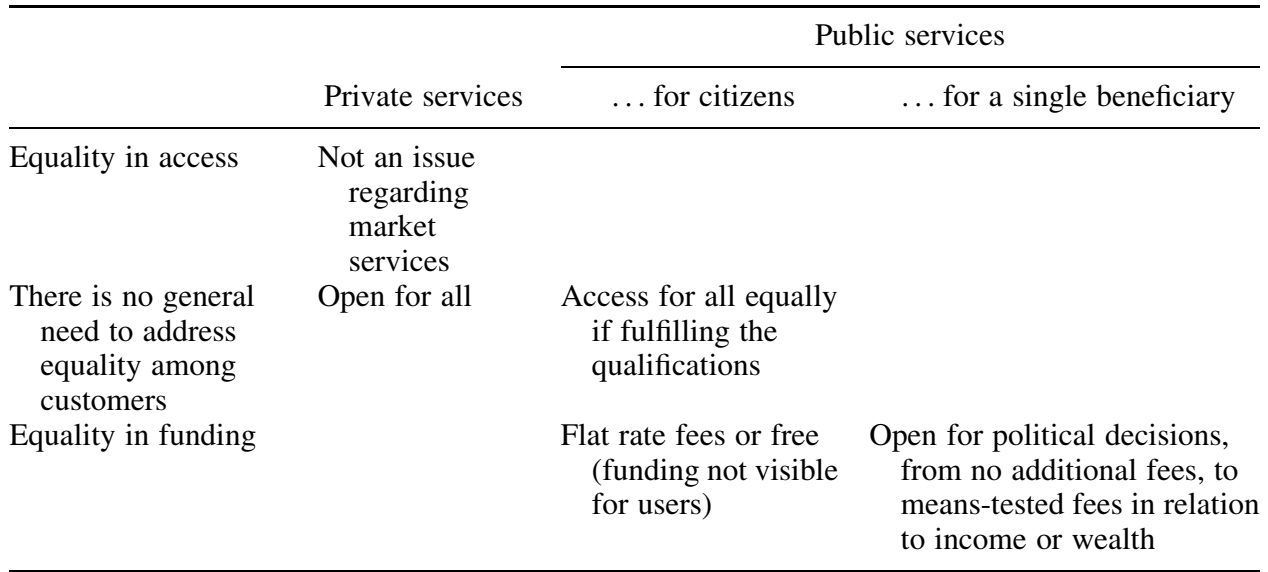

General public services for citizens are expected to be open for all. The accessibility to public services for all can be seen as a way to ensure equality. However, in relation to personal public services, in which the user is a single beneficiary, equality dictates that everyone should have access to services, such as emergency care, when needed. Public services are publicly funded, regardless of whether they are provided for a single beneficiary or the general public. Even when public services require additional fees, their shared funding bears part of the cost, in line with the equality argument. For market-provided services, there are no specific arrangements based on equality; the provider can even refuse service to a potential customer (Table 3).

The equality argument indicates that more elaborate aspects of equality must be integrated into QM models when applied to public services. Because these services are open to all, the experienced quality of the service is evaluated by a more heterogeneous group of users, including those who did not ask for the service. Providers of public services have no or limited options to make market segmentations.

\section{The third argument - Public services can be coercive}

The discussion above shows that even when public services must be equally arranged, not everyone can have access to all services at all times. On the other hand, some services are compulsory or even coercive. Such public services are provided even when not demanded, a situation that would never occur on a market in which private services are offered to those asking for and willing to pay for them.

As discussed earlier, public services are consequences of public interests, and are provided based on public decisions, in the interest of the general public. Coercive public services, funded through taxation, allow legitimate states to force their citizens to participate. Governments have the legal power to force citizens to act in line with legislation, both in general terms, such as paying taxes, and in maintaining law and order. But there are also services, which are not always seen as services that build the coercive power of the state. The previous example of the drug addict illustrates an opportunity for the government to force a citizen into compulsory care.

There are both compulsory public services, presented as positive favours provided by the state (such as school) that may include aspects of coerciveness, and pure coercive 
public 'services' related to what public policy considers unsuitable behaviour (such as coercive care of a drug abuser or speeding control by police). In both cases, the coerciveness of the service affects the experience of the service and, because there is no exit option, even a very good service can be experienced as a constraint. Therefore, the quality of a service should be evaluated within the constraints of its coerciveness.

The costs of coercive services are not directly related to the single user. Most public services are to different extents funded by public subsidies and the cost for the single user of the service is normally far from the total cost of the services. In the case of coercive services, the way in which costs are distributed is more complex. On the one hand when the main benefits are in the interest of the general public the costs are covered by public funds (taxes). For example, in coercive care of the drug addict there are subsidies (in the form of police and other emergency services) that in most Western states are fully covered by taxation. On the other hand, when it comes to coercive services with a single user, as in the example of the building permit above, the cost can partially or fully be transferred to the single beneficiary (Table 4). The key is, however, the price of the service is not negotiable and there are no alternatives for the services.

Since there are no forms of coerciveness in private services, it is an aspect that has been almost forgotten, or at least underdeveloped, in the field of QM. The impact of coerciveness makes the role of the customer a key issue. In theories of QM, the customer takes part freely and with full exit opportunity. However, when a citizen is forced to use a public service, they have no exit opportunity, and may also face negative consequences as a result of raising a complaint.

Based on this, QM for public services would benefit from addressing coerciveness. The manner in which coercive elements of public services are presented is essential to the experience of the quality of the service. In the same way, the flexibility of public services is limited within the legislative framework. Thus, also the possibilities to adjust services to personal needs and demands can be constrained, and also expressed and explained to the beneficiary in different ways. Together, they indeed influence the experienced quality of the service.

\section{The fourth argument - Public services contribute to political legitimacy}

All public activities must be legitimate in line with the legislation and the citizens' trust in the political system. Legitimacy is a key concept for the public sector as well as for political

Table 4. Coerciveness in relation to private and public services.

\begin{tabular}{|c|c|c|c|}
\hline & \multirow[b]{2}{*}{ Private services } & \multicolumn{2}{|c|}{ Public services } \\
\hline & & $\begin{array}{l}\ldots \text { for citizens in } \\
\text { general }\end{array}$ & $\ldots$ for a single user \\
\hline $\begin{array}{l}\text { Coerciveness to } \\
\text { use }\end{array}$ & $\begin{array}{l}\text { Coerciveness is not an } \\
\text { issue in relation to } \\
\text { market services }\end{array}$ & $\begin{array}{l}\text { General legislation } \\
\text { defines the power of } \\
\text { the state in relation } \\
\text { to its citizens }\end{array}$ & $\begin{array}{l}\text { Coerciveness is arranged in } \\
\text { specific legislation } \\
\text { regarding a particular } \\
\text { service }\end{array}$ \\
\hline $\begin{array}{l}\text { Coerciveness to } \\
\text { pay for } \\
\text { services }\end{array}$ & $\begin{array}{l}\text { Market actors are not } \\
\text { allowed to coerce } \\
\text { customers }\end{array}$ & $\begin{array}{l}\text { Generally paid for } \\
\text { through taxation }\end{array}$ & $\begin{array}{l}\text { A mix of systems, from fully } \\
\text { tax-based funding to fees } \\
\text { covering costs incurred by } \\
\text { the public provider }\end{array}$ \\
\hline
\end{tabular}


Table 5. Legitimacy in relation to private and public services.

\begin{tabular}{llc}
\hline & \multicolumn{1}{c}{ Private services } & Public services \\
\hline $\begin{array}{l}\text { Indication of } \\
\text { trust }\end{array}$ & Customer satisfaction & Transparency and political accountability \\
$\begin{array}{c}\text { Indication of } \\
\text { legality }\end{array}$ & $\begin{array}{c}\text { Following legal arrangements, } \\
\text { governmental control }\end{array}$ & $\begin{array}{c}\text { All services must fall within legal frames and } \\
\text { follow policy-based recommendations }\end{array}$ \\
\hline
\end{tabular}

processes, and provides the foundation for the three arguments made above regarding access to public services, equality, and coerciveness (cf. Christensen \& Lægreid, 2001; Örnerheim \& Wihlborg, 2014). In contrast to service providers in a market, public services provided by the state have to be legitimate in a broader sense (even market-based services must be legal). However, a private service provider can close down its business if customers lose interest in the service or do not trust the provider. A state cannot close down; it must earn the trust of its citizens. Thus, general elections, as an input to policy and legislation, express legitimacy, but the actual quality of public services has become a more important factor for political legitimacy (Rothstein \& Teorell, 2008).

Legitimacy thus becomes a component of quality, and is highlighted as a core aspect of the quality of governments (Rothstein, 2009). Generally, services in the public sector must address the general public, align with public values and norms, and be managed through legitimate processes (Table 5).

If QM is based on, and formed within, the legal framework, it may improve interpretations of legality, and support legitimacy (and thereby trust) in the governmental system. The World Bank's indictors of good governance are indicators of good quality in general (Kaufmann, Kraay, \& Mastruzzi, 2009), and may be used as indicators of high-quality public services (Rothstein, 2011; Rothstein \& Uslaner, 2005).

\section{Discussion}

The entry of QM has, according to critics, led to a public sector characterised by customerdriven activity that prioritises individual demands rather than needs and equity. Based on the conceptualisation of the arguments of rights and access, equality, coerciveness, and legitimacy, we would like to open up a discussion on the implications of QM practices in public services. The arguments discussed above are interrelated, not completely separable, and are in practice concatenated.

Firstly, not all services are accessible to everyone. Thus, the demand for a service cannot be viewed as an indicator that the customer finds the service attractive. The complex arrangements of rights and access to public services provide a unique mix for each service. The analysis of potential customers must be based on specific legislative framing, and in the governmental structuring of public services, which varies among states. QM programmes, thus, must embed methods regarding for whom and how access and rights to the service are legally arranged. For instance, public elderly care is only provided and accessible for those who fulfil the legally defined requirements.

Secondly, in contrast to market service, the QM of public services must address everyone equally. Customers who do not wish to use the services must be included, as well as customers the provider does not wish to serve. Thus, customers become a much more heterogeneous group that can evaluate the quality of services in more diverse ways. Since many QM programmes encompass prioritisation and stratification of customers into 
different groups, there might be a blindness towards equality aspects. This has to be addressed and focused on in further research.

Thirdly, elements of coerciveness must be addressed in new ways for QM. Because this is not included in QM for market services, new approaches must be developed. This is especially important when there are no exit opportunities for citizens as users. How the enforcements are organised, presented, and motivated can also be relevant indicators of the experience of the public service.

Finally, the QM of public services also has the potential to be a crucial feedback loop for political legitimacy since it is an outcome of the policy-making systems as expressed in political intentions, legislation, and the organisation of the public service delivery. Models of QM need to be integrated into public services in relation to the political values and policy aims discussed above. If models of QM are transferred, without translation, from a private sector context into public, the core values of the public and principles of services will be messed up or even hidden, and non-relevant indicators of quality might be applied.

We argue for more coherent models of QM in public services. These models require a more informed and elaborate understanding of the citizen with regard to democratic welfare models. In line with this, the QM of public services must be treated on a stateby-state basis, since all states have a (slightly) different institutional arrangement for legislation regarding public services and the types of welfare provided. Thus, international comparisons of public service quality must take into account institutional differences and policy ambitions. The legitimate governance of public services depends upon the provision of services within both institutional and legislative frames. Finally, new models of QM in public services should relate not only to the aims of the organisations providing public services, but also to their social and economic contexts. Based on these four arguments, there are openings both for new systems of QM in public services and for research on QM in public contexts.

Policy ambitions such as equality, sustainability, and regional development may be constraining and re-frame the public services. In different governmental contexts, different types of core values of the public have to guide the development of public services and thereby also evaluations of and research on such systems. The service provision may also contribute to part of larger policy programmes with more general aims. In order to contribute to the quality of government in general, the QM of a single public service must relate to, and be evaluated in line with, the broader ambitions of a high-quality public sector.

\section{Disclosure statement}

No potential conflict of interest was reported by the authors.

\section{References}

Agnafors, M. (2013). Quality of government: Toward a more complex definition. American Political Science Review, 107(3), 433-445.

Bejerot, E., \& Hasselbladh, H. (2013). Forms of intervention in public sector organizations: Generic traits in public sector reforms. Organization Studies, 34(9), 1357-1380.

Berwick, D. M. (1989). Continuous improvement as an ideal in health care. The New England Journal of Medicine, 320(1), 53-56.

Bouckaert, G., \& Peters, B. G. (2002). Performance measurement and management: The Achilles' heel in administrative modernization. Public Performance \& Management Review, 25(4), $359-362$.

Christensen, T., \& Lægreid, P. (2001). New public management: The transformation of ideas and practice. Aldershot: Ashgate. 
Dean, J. W., \& Bowen, D. E. (1994). Management theory and total quality: Improving research and practice through theory development. Academy of Management Review, 19(3), 392-418.

Deming, W. E. (1993). The new economics: For industry, government, education. Cambridge: MIT Press.

Elg, M., Palmberg Broryd, K., \& Kollberg, B. (2013). Performance measurement to drive improvements in healthcare practice. International Journal of Operations \& Production Management, 33(11/12), 1623-1651.

Elg, M., Stenberg, J., Kammerlind, P., Tullberg, S., \& Olsson, J. (2011). Swedish healthcare management practices and quality improvement work: Development trends. International Journal of Health Care Quality Assurance, 24(2), 101-123.

Esping-Andersen, G. (1990). The three worlds of welfare capitalism. Cambridge, MA: Polity Press.

Geels, F. W. (2010). Ontologies, socio-technical transitions (to sustainability), and the multi-level perspective. Research Policy, 39(4), 495-510.

Hood, C. (1991). Public management for all seasons? Public Administration, 69(1), 3-19.

Kaufmann, D., Kraay, A., \& Mastruzzi, M. (2009). Governance matters VIII: Aggregate and individual governance indicators, 1996-2008. World Bank Policy Research Working Paper (4978).

McAdam, R., Reid, R., \& Saulters, R. (2002). Sustaining quality in the UK public sector: Quality measurement frameworks. International Journal of Quality \& Reliability Management, 19(5), 581-595.

Morel, N., Palier, B., \& Palme, J. (2012). Towards a social investment welfare state? Ideas, policies and challenges. Bristol: Policy.

Moreland, N., \& Clark, M. (1998). Quality and ISO 9000 in educational organizations. Total Quality Management Business Excellence, 9(2-3), 311-320.

Nielsen, P. A. (2013). Performance management, managerial authority, and public service performance. Journal of Public Administration Research and Theory, 24, 431-458.

North, D. C. (1990). Institutions, institutional change and economic performance. Cambridge, MA: Cambridge University Press.

Örnerheim, M., \& Wihlborg, E. (2014). Path dependence on new roads. Institutional development of quality registers. Scandinavian Journal of Public Administration, 18(2), 3-22.

Pollitt, C. (2012). New perspectives on public services: Place and technology. Oxford: Oxford University Press.

Pollitt, C. (2013). The logics of performance management. Evaluation, 19(4), 346-363.

Pollitt, C., \& Bouckaert, G. (1999). Public management reform: A comparative analysis. Oxford: Oxford University Press.

Power, M. (1999). The audit society: Rituals of verification. Oxford: Oxford University Press.

Rothstein, B. (2009). Creating political legitimacy: Electoral democracy versus quality of government. American Behavioral Scientist, 53(3), 311-330.

Rothstein, B. (2011). The quality of government: Corruption, social trust and inequality in international perspective. Chicago: University of Chicago Press.

Rothstein, B., \& Teorell, J. (2008). What is quality of government? A theory of impartial government institutions. Governance, 21(2), 165-190.

Rothstein, B., \& Uslaner, E. M. (2005). All for all: Equality, corruption, and social trust. World Politics, 58(01), 41-72.

Schroeder, R. G., Linderman, K., \& Zhang, D. (2005). Evolution of quality: First fifty issues of production and operations management. Production and Operations Management, 14(4), 468-481.

Sousa, R., \& Voss, C. A. (2002). Quality management re-visited: A reflective review and agenda for future research. Journal of Operations Management, 20(1), 91-109.

Stringham, S. H. (2004). Does quality management work in the public sector. Public Administration and Management: An Interactive Journal, 9(3), 182-211.

Vedung, E. (2008). Public policy and program evaluation. Piscataway, NJ: Transaction.

Walby, S. (2009). Globalization and inequalities: Complexity and contested modernities. London: Sage.

Walker, R. M., \& Boyne, G. (2009). Introduction: Determinants of performance in public organizations. Public Administration, 87(3), 433-439.

Wiśniewska, M., \& Szczepańska, K. A. (2014). Quality management frameworks implementation in Polish local governments. Total Quality Management \& Business Excellence, 25(3-4), $352-366$. 